\title{
Laleh Khalili
}

\section{THE LOCATION OF PALESTINE IN GLOBAL GOUNTERINSURGENGIES}

Since at least the 1930s, Palestine has had a continuous role as a laboratory of counterinsurgency. During the British Mandate, Palestine saw a consolidation of the techniques of imperial policing and the development of a complex military-legal apparatus of control, from "security fences" and watchtowers to mass incarceration and collective punishment to emergency laws and administrative detention. Palestine has continued to be the setting for counterinsurgency military exercises, with Israel incorporating the British Mandate laws in its legal corpus and British military practice in its doctrines. Based on extensive primary research, this essay traces the development of counterinsurgency doctrine and practice and the legal apparatuses that uphold it and argues that both in the incorporation of British transmission of doctrine, law, and practice from Palestine, and in the Israeli military's deployment of new and transportable techniques of control, Palestine has been gradually transformed into a central node of military knowledge/power within a global matrix of counterinsurgency. 